\title{
Modeling and response analysis of the attitude angles of roadheader for steep coal seam
}

\author{
Kai Zong ${ }^{1}$ (D) Shichen $\mathrm{Fu}^{2} \cdot \mathrm{Miao} \mathrm{Wu}^{2}$
}

Received: 16 June 2020 / Accepted: 30 June 2021

Published online: 12 July 2021

(c) The Author(s) 2021 OPEN

\begin{abstract}
This study presents a dynamical model of the attitude angles of boom-type roadheader, to reveal the response characteristics of the attitude angles in steep coal seam. Based on the Lagrange equation, the dynamical model of the attitude angles of roadheader is established, then the simulation system is constructed in Simulink, to solve the dynamical model. Afterwards, a calculating method of the cutting load is proposed, to formulate the external loads of the roadheader during cutting process. Focused on the steep coal seam, of which the dip angle is $30^{\circ}$, the dynamical model is solved, and the solving results influenced by different factors are obtained. The results show that, the variations of roadheader's attitude are affected greatly by the cutting load, while the influence of swing angle of the cutting arm is relatively slight. Among the three attitude angles, the pitch angle varies most greatly, which can reach up to $9.1^{\circ}$ and $8.7^{\circ}$ during horizontal and vertical cutting process respectively. Finally, the numerical simulation results are verified by experimental data. The dynamical model and response characteristics of roadheader's attitude angle presented in this paper, can provide useful basis for prediction of roadheader's operating status and rectification of roadheader's attitude in steep coal seam.
\end{abstract}

\section{Article Highlights}

1. The dynamical model of roadheader's attitude is established, to accurately describe dynamic behaviors of roadheader during cutting process.
2. The response regularities of roadheader's attitude in steep coal seam, under effects of different factors, are revealed comprehensively.

3. A method to calculate the cutting load is proposed, upon which the three dimension forces on the cutting

head can be obtained.

Keywords Boom-type roadheader · Steep coal seam · Attitude angle · Dynamical model · Cutting load

Mathamtical Subject Classification 34K50

JEL Classification C60

\section{List of symbols}

$m_{1} /(\mathrm{kg}) \quad$ Quality of the cutting head

$m_{2} /(\mathrm{kg}) \quad$ Quality of the cutting arm

$m_{3} /(\mathrm{kg}) \quad$ Quality of the body

Kai Zong, zongkaiwd1991@163.com | 'Department of Mechanical Engineering, Tsinghua University, Beijing 100084, China. ${ }^{2}$ School of Mechanical Electronic and Information Engineering, China University of Mining and Technology, Beijing 100083, China.

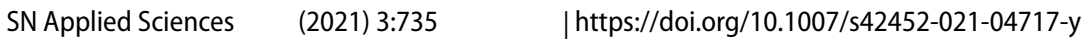




\begin{tabular}{|c|c|}
\hline$S_{Y} /(\mathrm{m})$ & Backward displacement of the body \\
\hline$S_{Z} /(m)$ & Floor-based displacement of the body \\
\hline$\theta_{1} /\left(^{\circ}\right)$ & Pitch angle of the body \\
\hline$\theta_{2} /\left(^{\circ}\right)$ & Roll angle of the body \\
\hline$\theta_{3} /\left(^{\circ}\right)$ & Deviation angle of the body \\
\hline$R_{X} /(\mathrm{N})$ & $\begin{array}{l}\text { Component force of the cutting load in the } \\
\text { horizontal direction }\end{array}$ \\
\hline$R_{Y} /(\mathrm{N})$ & $\begin{array}{l}\text { Component force of the cutting load per- } \\
\text { pendicular to the coal wall }\end{array}$ \\
\hline$R_{Z} /(\mathrm{N})$ & $\begin{array}{l}\text { Component force of the cutting load in the } \\
\text { vertical direction }\end{array}$ \\
\hline$F_{X} /(\mathrm{N})$ & $\begin{array}{l}\text { Friction between the crawler and the } \\
\text { ground in Xc-axis direction }\end{array}$ \\
\hline$F_{Y} /(\mathrm{N})$ & $\begin{array}{l}\text { Friction between the crawler and the } \\
\text { ground in } \mathrm{Y}_{\mathrm{c}} \text {-axis direction }\end{array}$ \\
\hline$L /(\mathrm{m})$ & $\begin{array}{l}\text { Distance between the centers of gyration of } \\
\text { the cutting arm and cutting head }\end{array}$ \\
\hline$L_{y} /(m)$ & $\begin{array}{l}\text { Distance between the center of gravity of } \\
\text { the cutting arm and its center of gyration }\end{array}$ \\
\hline$K_{1} /(\mathrm{N} / \mathrm{m})$ & $\begin{array}{l}\text { Stiffness between cutting head and cutting } \\
\text { arm }\end{array}$ \\
\hline$K_{2} /(\mathrm{N} / \mathrm{m})$ & $\begin{array}{l}\text { Stiffness between the cutting arm and the } \\
\text { body }\end{array}$ \\
\hline$K_{3} /(\mathrm{N} / \mathrm{m})$ & Stiffness between the body and the ground \\
\hline$C_{1} /(\mathrm{N} \mathrm{s} / \mathrm{m})$ & $\begin{array}{l}\text { Damping between cutting head and cutting } \\
\text { arm }\end{array}$ \\
\hline $\mathrm{C}_{2} /(\mathrm{N} \mathrm{s} / \mathrm{m})$ & $\begin{array}{l}\text { Damping between cutting arm and the } \\
\text { body }\end{array}$ \\
\hline$C_{3} /(\mathrm{N} \mathrm{s} / \mathrm{m})$ & $\begin{array}{l}\text { Damping between the body and the } \\
\text { ground }\end{array}$ \\
\hline$J_{X} /\left(\mathrm{Kg} \mathrm{m}^{2}\right)$ & Moment of inertia of the body about $\mathrm{X}_{\mathrm{b}}$-axis \\
\hline$\hat{J_{Y}} /\left(\mathrm{Kg} \mathrm{m}^{2}\right)$ & Moment of inertia of the body about $Y_{b}$-axis \\
\hline$J_{Z} /\left(\mathrm{Kg} \mathrm{m}^{2}\right)$ & Moment of inertia of the body about $Z_{b}$-axis \\
\hline$a /(\mathrm{m})$ & $1 / 2$ Of the body's width \\
\hline$b /(\mathrm{m})$ & $1 / 2$ Of the body's length \\
\hline
\end{tabular}

\section{Introduction}

Over decades, the mining depth of coal seam keeps increasing in China's coal industry, which has exceeded $1000 \mathrm{~m}$ in many coal mines. [1] Due to constantly mining, the coal resources in many mines are exhausted. As a result, mining of some steep coal seams is getting more and more attention [2]. The drivage operation of roadway is one of the most important and difficult production links in coal mining, which is faced with great difficulty and risk in deep and steep coal seam [3]. Therefore, solutions of key basic problems in the fully mechanized excavation face is becoming more and more urgent [4].

As a kind of mining equipment widely used in China's coal industry, boom-type roadheader is the main equipment in fully mechanized excavation face [5], whose function is driving the roadway and preparing working face for coal cutter, to finish coal mining. The application of boom-type roadheader greatly improves the driving speed and efficiency of the roadway, but some critical problems accompanied with the application of roadheader need to be solved urgently. In some deep and steep coal seams, coal and rock are unevenly distributed. Consequently, the actual load on the cutting head is continuously varying, during cutting process of roadheader $[6,7]$. Besides, the geological conditions of the fully mechanized excavation face in steep coal seam is extremely complex $[8,9]$, and the physical structure of roadheader itself is quite complicated. To be specific, the dip angle of coal seam and swing angle of roadheader's cutting arm will influence the operating status of roadheader. As a result, the attitude of roadheader varies constantly during cutting process under influence of above harsh conditions, which seriously influences the actual drivage direction of roadheader and reduces forming quality of the roadway [10]. Therefore, the response characteristics of roadheader's attitude during cutting process, is the primary key basic problem in the fully mechanized excavation face, which need to be studied and obtained urgently.

In related aspects, some researchers have conducted some researches already. Li and Zhao [11, 12] established the mathematical model for the whole unit of roadheader based on Lagrange equation, then analyzed the vibration response characteristics of the cutting arm and the body under random excitation through solution of the dynamic model by Matlab. Yao et al. [13] established the mathematical model of roadheader's travel unit based on Lagrange equation, and analyzed the horizontal and vertical vibration characteristics of the travel unit through simulation analysis. He et al. [14] established the three dimensional entity model of boom-type roadheader by using Pro/E, and conducted the modal analysis of the whole machine by Adams, finally the vibration characteristics of the cutting head, cutting arm and the body in different working conditions were obtained. Li et al. [15] established the kinematic model of roadheader's cutting arm in the roadway space based on differential geometry theory, then obtained the numerical solution of the kinematic equation through Newton iteration method, finally obtained the motion response of the cutting arm. Wang et al. [16] established the three-dimensional entity model of roadheader's cutting arm, and analyzed the vibration characteristics and dynamic load of the cutting arm during cutting process through dynamic simulation and experimental research.

It can be concluded that, there are two approaches for modeling and simulation analysis of roadheader, dynamical equation method and solid modeling method. A few studies established the dynamical model of subsystems of roadheader, mainly for analysis of random vibration 
response. In most studies, the solid modeling method is adopted to construct the three-dimensional solid model of roadheader, for modal and kinematic analysis of key structures. The existing theoretical models haven't involve the attitude angels of roadheader, and the solid modeling method is not focused on the mechanism of dynamic behaviors of roadheader.

It is worth noting that, We have analyzed the body pose responses of boom-type roadheader during the horizontal cutting process [17], and the multibody large-scale displacement responses of roadheader during the vertical cutting process [18], aiming at the flat coal seams. However, concerning the steep coal seams, which are much different from the flat coal seams, theoretical model and response characteristics of roadheader's attitude are still none reported in existed literatures. It is a quite significant problem for China's coal industry now, and needs to be settled urgently.

Motivated by the above situation, our work in this paper is focused on the condition of steep coal seams, to reveal the response characteristics of the attitude angles of roadheader during horizontal and certical cutting process, through theoretical modeling, numerical analysis and experimental verification. In Sect. 2, the definitions of the attitude angles of roadheader are illustrated, then the dynamical model of the attitude angles is established based on the Lagrange equation. In Sect. 3, a calculating method of the cutting load is proposed, and triaxial forces on the cutting head are calculated, taking the EBZ160 boom-type roadheader for example. In Sect. 4, the Simulink simulation method is adopted to construct the simulation system and solve the dynamical model of the attitude angles, afterwards the response characteristics of the attitude angles under different influence factors are obtained through parametric analysis. In Sect. 5, the simulation results are verified by experimental data. Finally, some crucial conclusions of the research work are summarized in Sect. 6.

\section{Dynamical model of the attitude}

The attitude of roadheader can be expressed and described by three variables together, which are the pitch angle, roll angle and deviation angle. It can be assumed that, the stiffness and damping between the cutting head and cutting arm are $K_{1}$ and $C_{1}$, the stiffness and damping between the cutting arm and the body are $K_{2}$ and $C_{2}$, and the stiffness and damping between the body and the ground are $K_{3}$ and $C_{3}$. The quality of cutting head, cutting arm and the body are $m_{1}, m_{2}$ and $m_{3}$, respectively. The cutting load is from the coal wall and only acted on the cutting head during cutting process, hence it can be described by triaxial forces, whose directions are horizontal direction, vertical direction and direction perpendicular to the coal wall.

The mechanical model diagram of roadheader is shown in Fig. 1 [18]. The fixed coordinate system $O_{c} X_{c} Y_{c} Z_{c}$ represents the roadway space, while the moving coordinate system $\mathrm{O}_{b} \mathrm{X}_{b} \mathrm{Y}_{b} \mathrm{Z}_{\mathrm{b}}$ is fixed on roadheader and moves with the roadheader. The $X_{c}$-axis and $X_{b}$-axis are in the horizontal direction, $Y_{c}$-axis and $Y_{b}$-axis are perpendicular to the coal wall, and $Z_{c}$-axis and $Z_{b}$-axis are in the vertical direction.

The dip angle of coal seam $\varphi$, is a key parameter in modeling and parametric analysis, which indicates the condition of steep coal seam quantificationally. Despite the complicated structure of roadheader, it can be regarded as a complete system during cutting process through

(a)

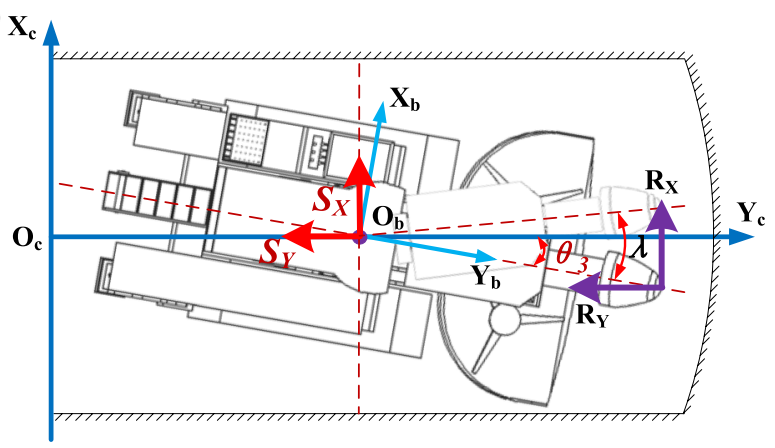

(b)

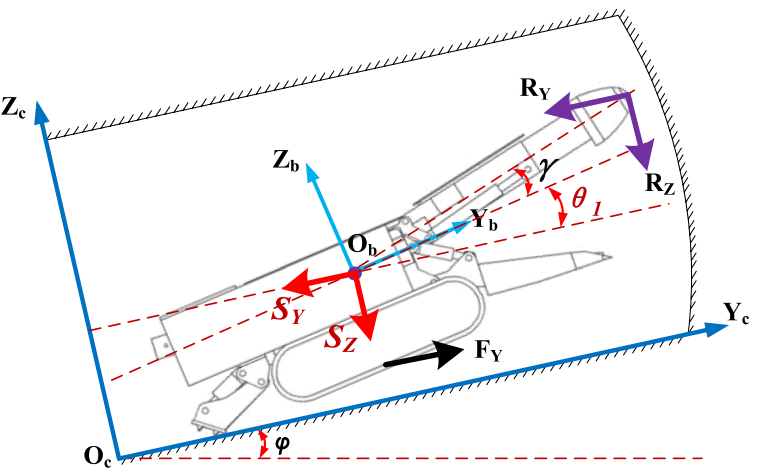

(c)

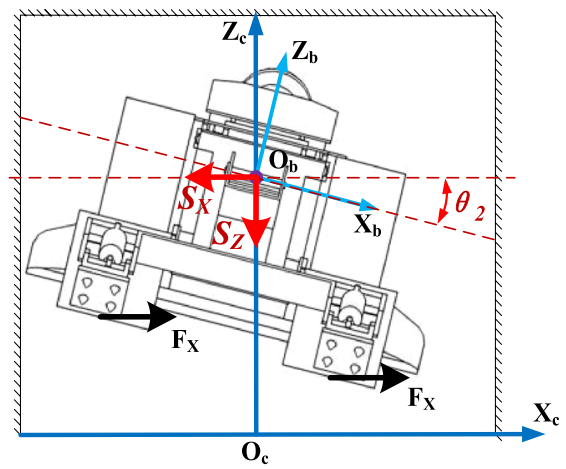

Fig. 1 Mechanical model diagram of roadheader. (a) Vertical view; (b) Left view; (c) Rear view 
considering the stiffness and damping between different parts, so that the motion differential equations of the three attitude angles of roadheader' body can be derived through multi-body dynamics modeling method.

The Lagrange equation is applied to dynamics modeling in this paper, which is introduced as [19]:

$\frac{d}{d t}\left(\frac{\partial T}{\partial \dot{q}_{i}}\right)-\frac{\partial T}{\partial q_{i}}=Q_{i}$

Rayleigh dissipation function $D$ is introduced, so Eq. (1) can be transformed into:

$\frac{d}{d t}\left(\frac{\partial T}{\partial \dot{q}_{i}}\right)-\frac{\partial T}{\partial q_{i}}+\frac{\partial D}{\partial \dot{q}_{i}}=Q_{i}$

The potential forces are separated from the right side, and the energy function $U\left(q_{i}\right)$ is introduced, finally Eq. (2) can be transformed into:

$\frac{d}{d t}\left(\frac{\partial T}{\partial \dot{q}_{i}}\right)-\frac{\partial T}{\partial q_{i}}+\frac{\partial D}{\partial \dot{q}_{i}}+\frac{\partial U}{\partial q_{i}}=Q_{i}$

In Eq. (3), $T$ is the kinetic energy of the roadheader system, $D$ is the dissipative energy, $U$ is the potential energy, $q_{i}$ is the generalized coordinate, $i$ is the number of generalized coordinate, and $Q_{i}$ is the generalized force.

Based on Eq. (3), the dynamical model of roadheader's attitude will be established through energy method in following parts.

The process of cutting a cross-section by roadheader is composed of horizontal cutting process and vertical cutting process, which are conducted alternately until the whole cross-section is cut out, as shown in Fig. 2. Therefore, the dynamical model of roadheader's attitude should be derived aiming at horizontal and vertical cutting process respectively.

Take the condition of horizontal cutting process and as example, the kinetic energy $T$, potential energy $U$ and dissipative energy $D$ of the roadheader system during horizontal cutting process are derived.

Taking the pitch angle as example, and substituting $T, U$ and $D$ into Eq. (3), the following equations can be derived:

$\frac{d}{d t}\left(\frac{\partial T}{\partial \dot{\theta}_{1}}\right)=J_{X} \ddot{\theta}_{1}$

$\frac{\partial T}{\partial \theta_{1}}=0$

$\frac{\partial D}{\partial \dot{\theta}_{1}}=b^{2} C_{3} \dot{\theta}_{1}+b C_{3} \dot{S}_{Z}$

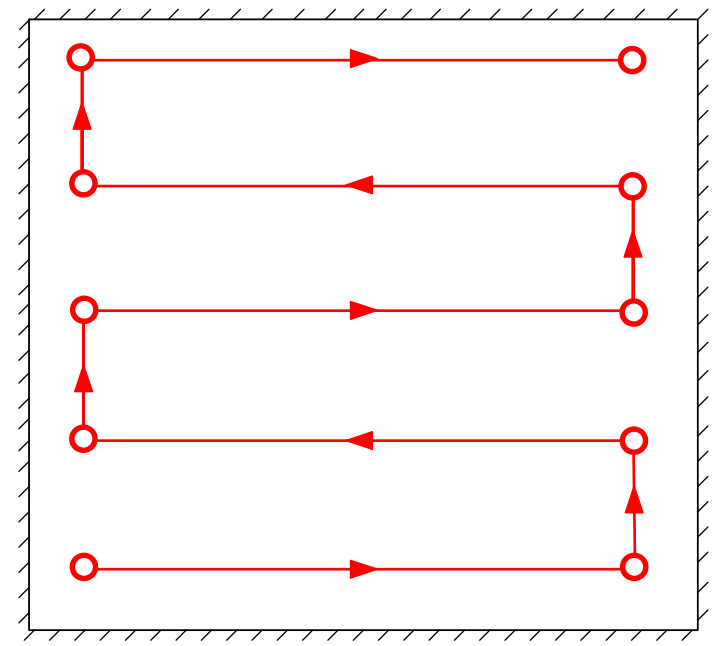

Fig. 2 Schematic diagram of moving path of the cutting head

$$
\begin{aligned}
\frac{\partial U}{\partial \theta_{1}}= & \left(m_{1}+m_{2}+m_{3}\right) g\left[S_{Z} \sin \left(\varphi-\theta_{1}\right)-S_{Y} \cos \left(\varphi-\theta_{1}\right)\right] \\
& -\left(m_{2}+m_{3}\right) g L_{\alpha} \cos \left(\alpha+\varphi-\theta_{1}\right) \\
& -\left(m_{1} L+m_{2} L_{y}\right) g \cos \left(\gamma+\varphi-\theta_{1}\right)+K_{3} b^{2} \theta_{1}+K_{3} b S_{Z} \\
& +K_{1}\left[L \sin \left(\gamma+\varphi-\theta_{1}\right)-L \sin (\gamma+\varphi)-b \sin \theta_{2}\right. \\
& \left.+S_{Y} \sin \left(\varphi-\theta_{1}\right)+S_{Z} \cos \left(\varphi-\theta_{1}\right)+S_{X} \sin \theta_{2}\right]\left[S_{Z} \sin (\varphi\right. \\
& \left.\left.-\theta_{1}\right)-L \cos \left(\gamma+\varphi-\theta_{1}\right)-S_{Y} \cos \left(\varphi-\theta_{1}\right)\right] / \cos ^{2} \gamma
\end{aligned}
$$

Assuming the generalized force of the system is expressed by $M_{\theta_{1}}$, then

$$
\begin{aligned}
M_{\theta_{1}}= & R_{Z}(L \cos \gamma \cos \lambda+b) \\
& +\left(m_{1}+m_{2}\right)\left(L_{y} \cos \gamma \cos \lambda+b\right) g
\end{aligned}
$$

Substituting above equations into Eq. (3), the motion differential equation of the pitch angle is derived as:

$$
\begin{aligned}
& J_{X} \ddot{\theta}_{1}+b^{2} C_{3} \dot{\theta}_{1}+b^{2} K_{3} \theta_{1}+\left(m_{1}+m_{2}+m_{3}\right) g\left[S_{Z} \sin \left(\varphi-\theta_{1}\right)\right. \\
& \left.-S_{Y} \cos \left(\varphi-\theta_{1}\right)\right]-\left(m_{2}+m_{3}\right) g L_{\alpha} \cos \left(\alpha+\varphi-\theta_{1}\right)-\left(m_{1} L\right. \\
& \left.+m_{2} L_{y}\right) g \cos \left(\gamma+\varphi-\theta_{1}\right)+K_{1}\left[L \sin \left(\gamma+\varphi-\theta_{1}\right)\right. \\
& -L \sin (\gamma+\varphi)-b \sin \theta_{2}+S_{Y} \sin \left(\varphi-\theta_{1}\right)+S_{Z} \cos \left(\varphi-\theta_{1}\right) \\
& \left.+S_{X} \sin \theta_{2}\right]\left[S_{Z} \sin \left(\varphi-\theta_{1}\right)-L \cos \left(\gamma+\varphi-\theta_{1}\right)\right. \\
& \left.-S_{Y} \cos \left(\varphi-\theta_{1}\right)\right] / \cos ^{2} \gamma+b C_{3} \dot{S}_{Z}+b K_{3} S_{Z} \\
& =R_{Z}(L \cos \gamma \cos \lambda+b)+\left(m_{1}+m_{2}\right)\left(L_{y} \cos \gamma \cos \lambda+b\right) g
\end{aligned}
$$

Similarly, the motion differential equation of the pitch angle during vertical cutting process is derived, and the result is the same as Eq. (9). After similar derivation, it indicates that the motion differential equations of the roll angle during horizontal and vertical cutting process also have the same form, as shown in Eq. (10), but the motion 
differential equations of the deviation angle during horizontal and vertical cutting process are different, as shown in Eq. (11).

$$
\begin{aligned}
& J_{Y} \ddot{\theta}_{2}+a^{2} C_{3} \dot{\theta}_{2}+a^{2} K_{3} \theta_{2}+\left[\left(m_{1}+m_{2}+m_{3}\right) g S_{X}\right. \\
& \left.-\left(m_{1}+m_{2}\right) g b\right] \cos \theta_{2}+K_{1} \cos \theta_{2}\left(S_{X}-b\right)[L \sin (\gamma \\
& \left.+\varphi-\theta_{1}\right)-L \sin (\gamma+\varphi)-b \sin \theta_{2}+S_{Y} \sin \left(\varphi-\theta_{1}\right) \\
& \left.+S_{Z} \cos \left(\varphi-\theta_{1}\right)+S_{X} \sin \theta_{2}\right] / \cos ^{2} \gamma+a C_{3} \dot{S}_{Z}+a K_{3} S_{Z} \\
& =R_{Z}\left(L \sin \gamma \sin \lambda+L_{\alpha}\right)+\left(m_{1}+m_{2}\right)\left(L_{y} \sin \gamma \sin \lambda+L_{\alpha}\right) g
\end{aligned}
$$

$$
\left\{\begin{array}{r}
J_{Z} \ddot{\theta}_{3}+C_{3} \dot{\theta}_{3}+K_{3} \theta_{3}-R_{X} b \cos \theta_{3}=R_{X} L \cos \gamma \cos \lambda \\
\text { Horizontal cutting process } \\
J_{Z} \ddot{\theta}_{3}+C_{3} \dot{\theta}_{3}+K_{3} \theta_{3}-R_{Z} b \cos \theta_{3}=R_{Z} L \cos \gamma \cos \lambda \\
\text { Vertical cutting process }
\end{array}\right.
$$

Equations (9-11) are the dynamical model of roadheader's attitude.

\section{Calculating method of the cutting load}

Obviously, the actual load acted on the cutting head by coal wall is the most important primitive factor of the variation of roadheader's attitude, and it can be seen from the dynamical model that the cutting load must be confirmed before solving the differential equations. Since the situation of uneven distribution of coal and rock in the coal seam, it's difficult to obtain regular and useful cutting load spectrum directly by field test, while the method of virtual load construction is inadequate for quantitative analysis of response of roadheader's attitude. Therefore, a calculating method of the cutting load is proposed to solve the problem in this paper.

The coal is cut down under the cooperation of swing of the cutting arm and rotation of the cutting head. The horizontal swing process of the cutting arm is driven by the angling cylinders, and the vertical swing process is driven by the lifting cylinders. The picture of real product is shown in Fig. 3. During the cutting process, as the hardness of

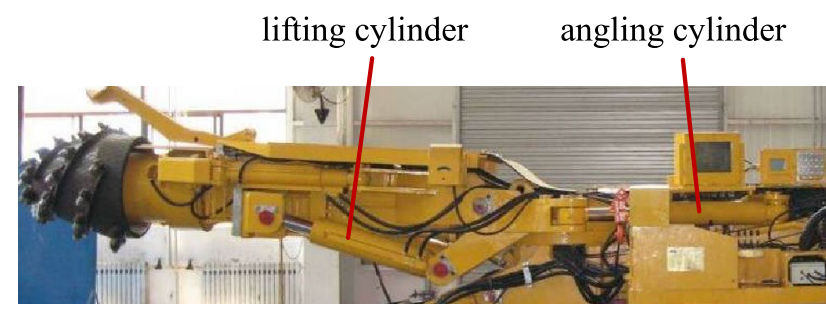

Fig. 3 Picture of real product of the cutting arm coal and rock is changing, the pressure of angling cylinders or lifting cylinders is also changing accordingly with a kind of positive correlation $[20,21]$. Theoretically, the crushing force of the cutting head acted on the coal wall can be computed by the pressure of angling cylinders and lifting cylinders, and the pressure of cylinders can be accurately measured at real time. According to Newton's third law, the cutting load equals to the crushing force, and the calculating method of its component forces can be derived based on moment balance principle.

The angling cylinders are a pair of symmetrically arranged cylinders, while the lifting cylinders are a pair of parallelly and symmetrically arranged cylinders. The schematic diagrams of horizontal and vertical swing process of the cutting arm are shown in Figs. 4, 5. Point $O$ is the center of gyration of the revolving platform, and point $O^{\prime}$ is the hinge point of the cutting arm and revolving platform. Point $A$ and $D$ are the hinge points of angling cylinders and revolving platform, point $B$ and $C$ are the hinge points of angling cylinders and the frame, point $E$ is the hinge point of lifting cylinder and revolving platform, and point $F$ is the hinge point of lifting cylinder and the cutting arm. Point $R$ is the force bearing point of the cutting head.

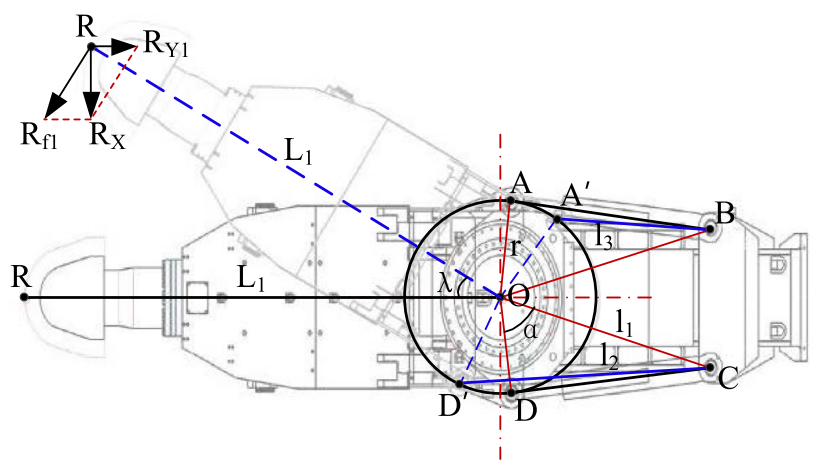

Fig. 4 Schematic diagram of horizontal swing process of the cutting arm

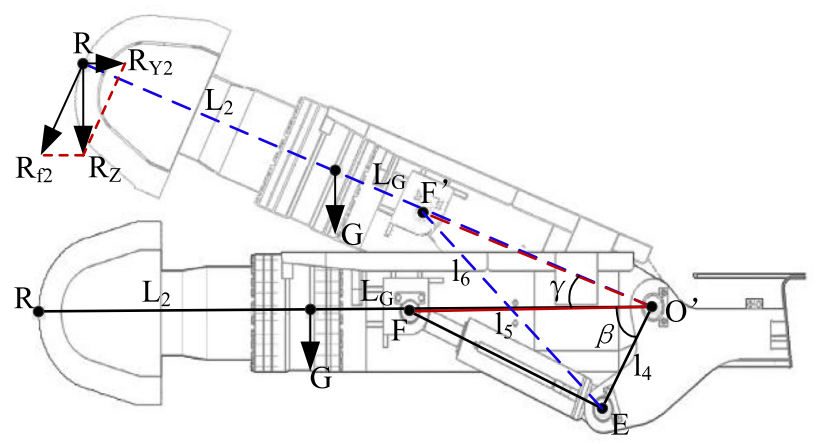

Fig. 5 Schematic diagram of vertical swing process of the cutting arm 
In Fig. $4, \overline{O B}=\overline{O C}=l_{1}, \overline{O R}=L_{1}, \angle A O B=\angle C O D=\alpha$, and the radius of revolving platform is $\overline{O A}=\overline{O D}=r$. During the horizontal swing process, after the cutting arm swings a certain angle $\lambda$, point $A$ will move to point $A^{\prime}$, and point $D$ will move to point $D^{\prime}$, then $\overline{C D^{\prime}}=I_{2}, \overline{A B^{\prime}}=I_{3}$. In Fig. 5, $\overline{O^{\prime} E}=I_{4}, \overline{O^{\prime} F}=I_{5}, \overline{O^{\prime} R}=L_{2}, \angle E O^{\prime} F=\beta$, and the distance between cutting arm's center of gravity and point $O^{\prime}$ is $L_{G}$. During the vertical swing process, after the cutting arm swings a certain angle $\gamma$, point $F$ will move to point $F^{\prime}$, then $\overline{E F^{\prime}}=I_{6}$.

During horizontal swing process of the cutting arm, it can be assumed that point $O$ is the center of moments, then the push moment of one angling cylinder is:

$M_{T}=\left[P_{1} S_{1} r l_{1} \sin (\alpha+\lambda)\right] / I_{2}$

The pull moment of the other angling cylinder is:

$M_{L}=\left[P_{1}\left(S_{1}-S_{2}\right) r I_{1} \sin (\alpha-\lambda)\right] / I_{3}$

The resistance moment of the cutting load is:

$M_{1}=R_{f 1} L_{1} \cos \gamma$

According to the moment balance principle, the circumferential force of the cutting head in the horizontal direction can be derived as:

$R_{f 1}=\frac{P_{1} r I_{1}\left[I_{3} S_{1} \sin (\alpha+\lambda)+I_{2}\left(S_{1}-S_{2}\right) \sin (\alpha-\lambda)\right]}{I_{2} I_{3} L_{1} \cos \gamma}$

In Eq. (15), $P_{1} /(\mathrm{Pa})$ is the pressure of the angling cylinders, $S_{1} /\left(\mathrm{m}^{2}\right)$ is the cross-sectional area of the cylinder, and $S_{2} /\left(\mathrm{m}^{2}\right)$ is the cross-sectional area of the pole.

Therefore, the component force of the cutting load in the horizontal direction is:

$$
\begin{aligned}
R_{X} & =R_{f 1} \cos \lambda \\
& =\frac{P_{1} r I_{1} \cos \lambda\left[I_{3} S_{1} \sin (\alpha+\lambda)+I_{2}\left(S_{1}-S_{2}\right) \sin (\alpha-\lambda)\right]}{I_{2} I_{3} L_{1} \cos \gamma}
\end{aligned}
$$

During vertical swing process of the cutting arm, assuming that point $O^{\prime}$ is the center of moments, then the resistance moment of the cutting load is:

$M_{2}=R_{f 2} L_{2} \cos \lambda$

The gravity moment of the cutting arm is:

$M_{G}=\left(m_{1}+m_{2}\right) g L_{G} \cos \lambda \cos \gamma$

The push moment of the lifting cylinders is:

$M_{S}=\left[2 P_{2} S_{3} I_{4} I_{5} \sin (\gamma+\beta)\right] / I_{6}$

Then the circumferential force of the cutting head in the vertical direction can be derived as:
$R_{f 2}=\frac{2 P_{2} S_{3} I_{4} I_{5} \sin (\gamma+\beta)}{I_{6} L_{2} \cos \lambda}-\frac{\left(m_{1}+m_{2}\right) g L_{G} \cos \gamma}{L_{2}}$

In Eq. (20), $P_{2} /(\mathrm{Pa})$ is the pressure of the lifting cylinders, and $S_{3} /\left(\mathrm{m}^{2}\right)$ is the cross-sectional area of the cylinder.

Therefore, the component force of the cutting load in the vertical direction is:

$$
\begin{aligned}
R_{Z} & =R_{f 2} \cos \gamma \\
& =\frac{2 P_{2} S_{3} I_{4} I_{5} \cos \gamma \sin (\gamma+\beta)}{I_{6} L_{2} \cos \lambda}-\frac{\left(m_{1}+m_{2}\right) g L_{G} \cos ^{2} \gamma}{L_{2}}
\end{aligned}
$$

In conclusion, Eq. (16) and Eq. (21) are the calculating formulas of the cutting load. Based on the field measured data of EBZ-160 type roadheader, the cutting load is calculated according to the proposed method. The pressures of angling cylinders and lifting cylinders are shown in Fig. 6, and the calculating results are shown in Fig. 7.

(a)

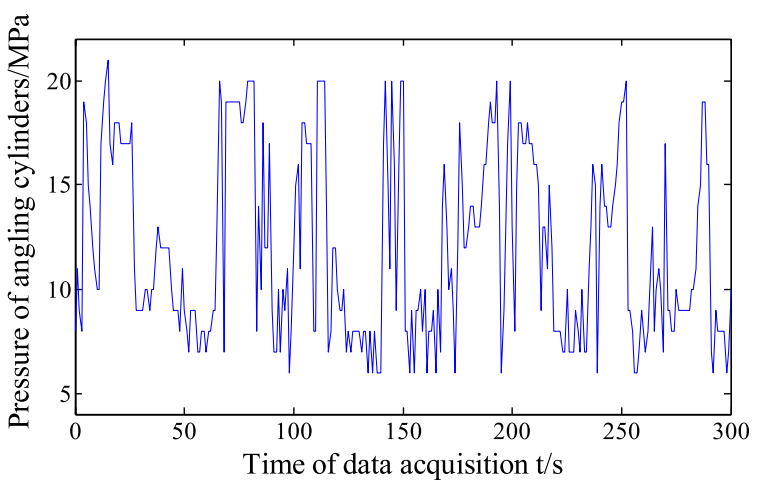

(b)

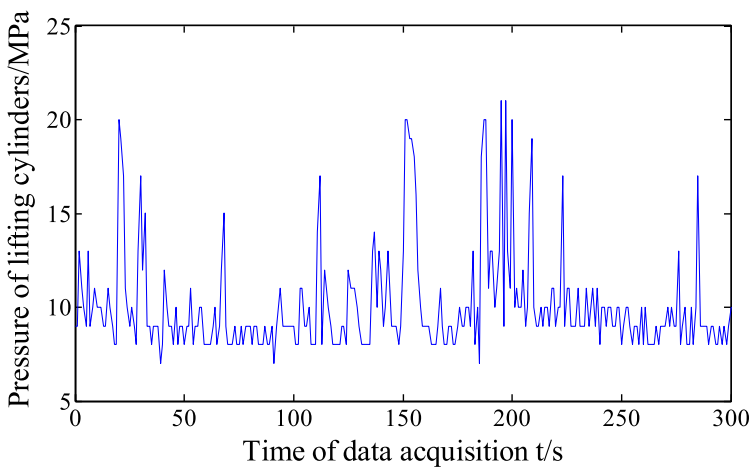

Fig. 6 Pressure of the driving cylinders measured in field. (a) Pressure of angling cylinders; (b) Pressure of lifting cylinders 


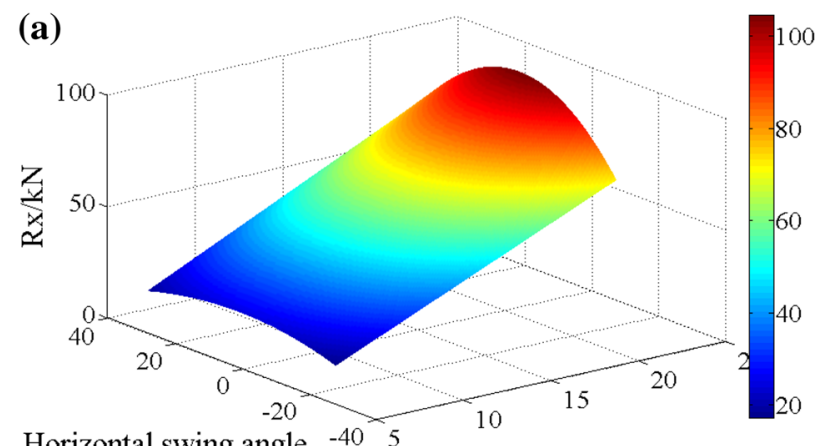

Horizontal swing angle -40 of the cutting arm $\lambda\left({ }^{\circ}\right)$

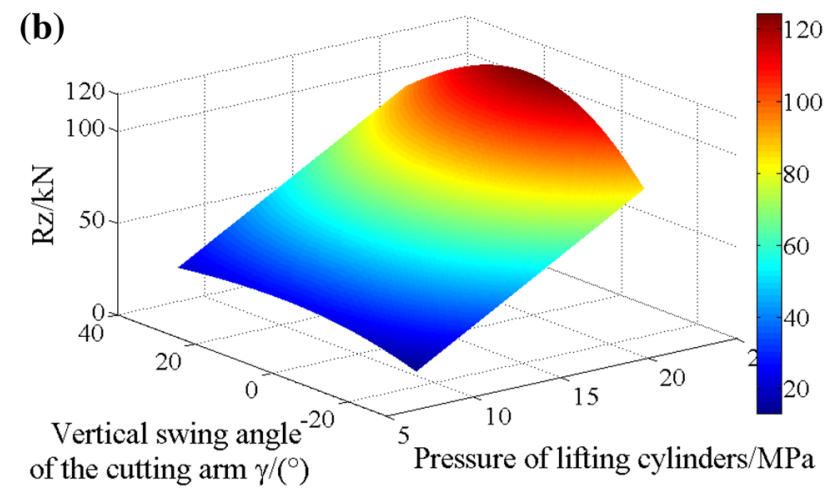

Fig. 7 Calculating results of the cutting load. (a) Component force $R_{\chi i}$ (b) Component force $R_{Z}$

\section{Simulation analysis}

\subsection{Simulation system in Simulink}

It can be easily seen from Eqs. (9-11) that, the established dynamical model is a multivariate and second-order differential equation set, whose analytical solutions are unobtainable. Simulink simulation method has incomparable advantages in numerical solution of complex differential equations. Therefore, Simulink software is utilized to establish the simulation system, and then to solve the established dynamical model, as shown in Fig. 8. The solution algorithm is the forth/fifth-order Runge-Kutta method (ode 45).

Taking the EBZ-160 type roadheader as an example, the moments of inertia of roadheader's body are obtained through theoretical calculation, the values of quality and size parameters are obtained from the machine specifications, and the stiffness and damping coefficients are from related references of the same or similar type of roadheader. The initial parameters and the values for simulation are shown in Table 1 [22-24].

It is worth noting that, among the parameters in the established model, the attitude angles, $\theta_{1}, \theta_{2}$ and $\theta_{3}$, are to be solved in simulations, and are measured in experiments to verify the simulation results. The swing angle of the cutting arm, $\lambda$ and $\gamma$, and dip angle of coal seam $\varphi$, are measured directly. The cutting load, $R_{X}$ and $R_{Z}$, are calculated by the proposed method in Sect. 3 , of which the pressures of the driving cylinders, $P_{1}$ and $P_{2}$, are directly measured. Besides, parameters in Table 1, Eq. (16 and 21), are inherent parameters of roadheader itself, are obtained from the specifications and references.

\subsection{Analysis of the solving results}

In coal geology, the coal seam with dip angle of $25^{\circ}-45^{\circ}$ is defined as inclined seam, belonging to steep coal seam [25]. This paper mainly analyzed the responses of the attitude angles during cutting process, at the dip angle of $30^{\circ}$. In the two conditions of horizontal and vertical cutting process, the dynamical model of the attitude is solved, and the solving results are processed and analyzed with different influence factors.

\subsubsection{Influence of the dip angle of coal seam}

The solving results of the dynamical model are analyzed with the dip angle of steep coal seam, as shown in Fig. 9. In the dip angle range of steep coal seam, when the dip angle of coal seam increases, the pitch angle $\theta_{1}$ increases at first and reaches to a stable value gradually in both of the horizontal and vertical cutting process, but the variation amplitude in the horizontal cutting process is bigger than that in the vertical cutting process. The roll angle $\theta_{2}$ increases with increase of dip angle of coal seam in the vertical cutting process, but it shows a small range fluctuation in the horizontal cutting process. There is no existence of parameter $\varphi$ in the differential equations of the deviation angle, therefore it can be concluded that the dip angle of coal seam has no influence on the change of deviation angle. 
(a)

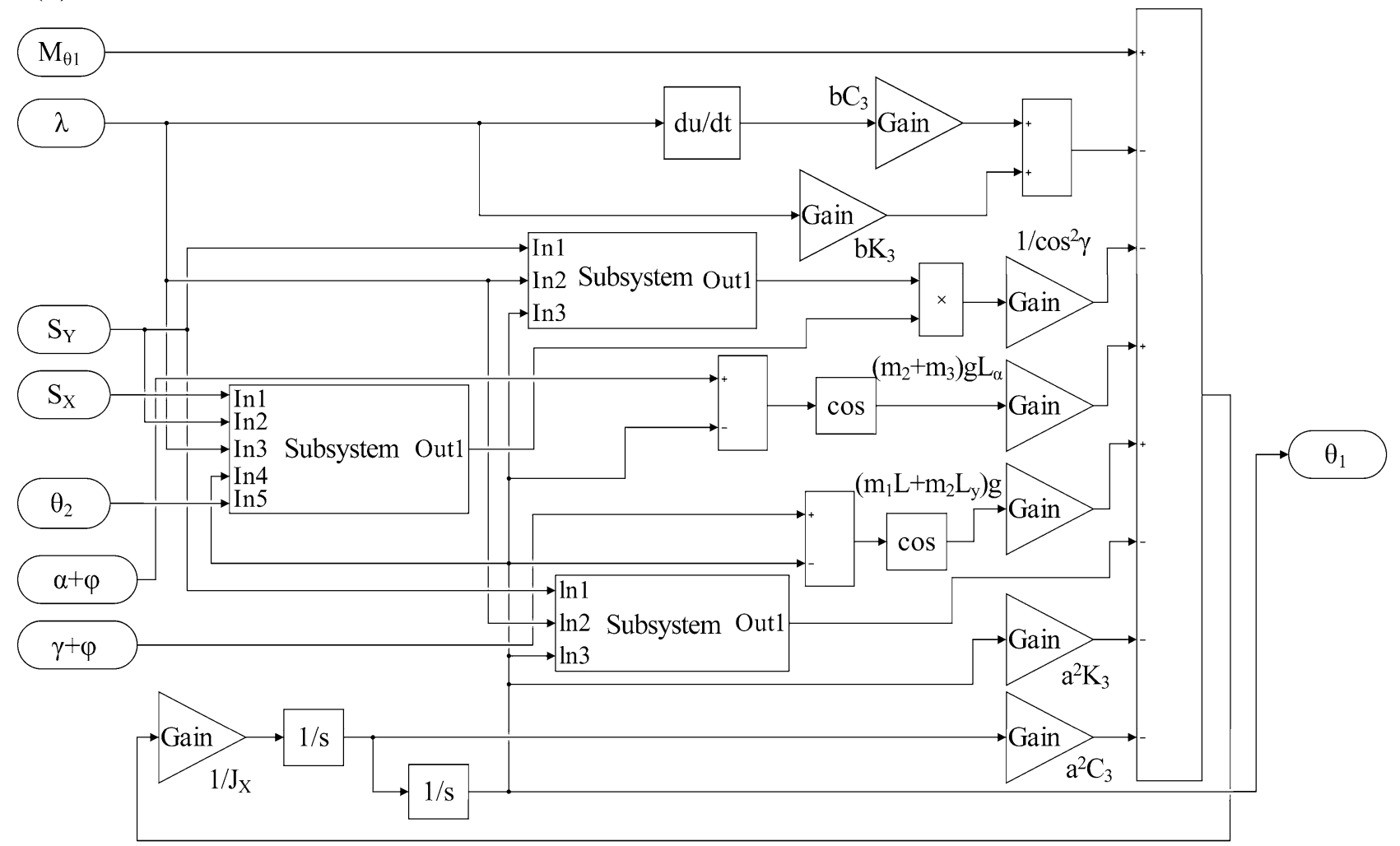

(b)

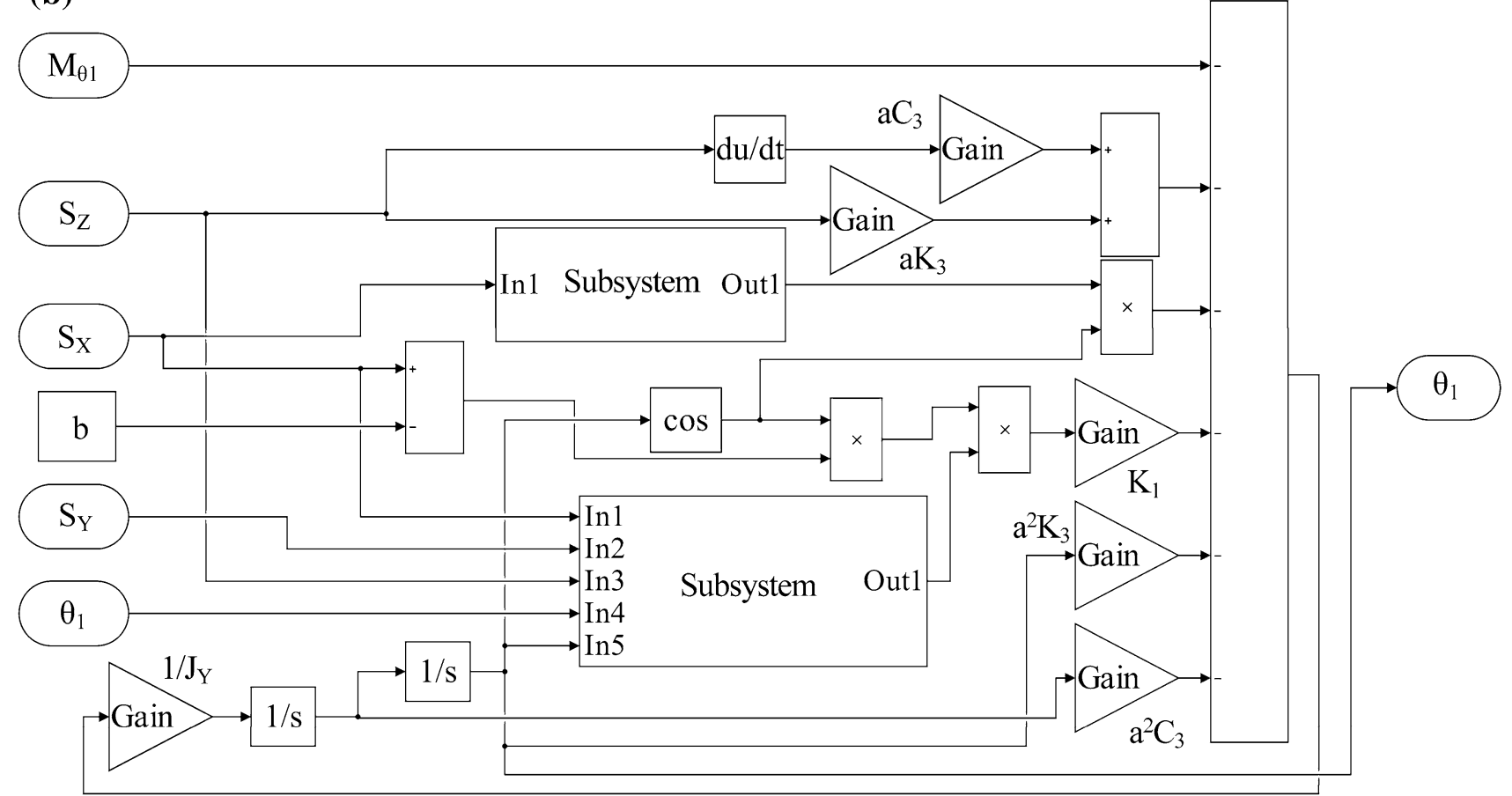

Fig. 8 Simulink system of solving the dynamical model. (a) Solving the pitch angle $\theta_{1}$ ( (b) Solving the roll angle $\theta_{2}$; (c) Solving the deviation angle $\theta_{3}$ during horizontal cutting process; (d) Solving the deviation angle $\theta_{3}$ during vertical cutting process 
(c)

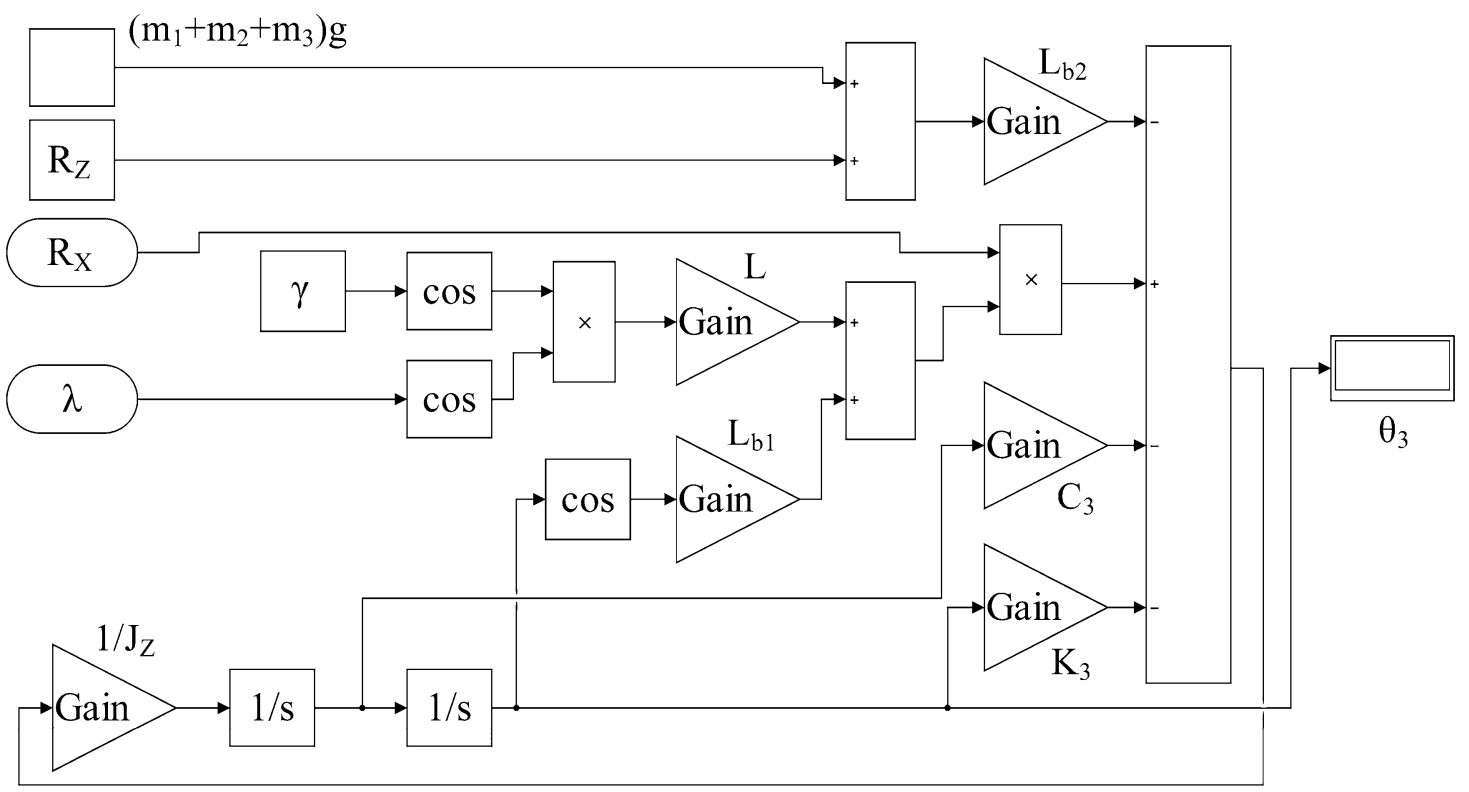

(d)

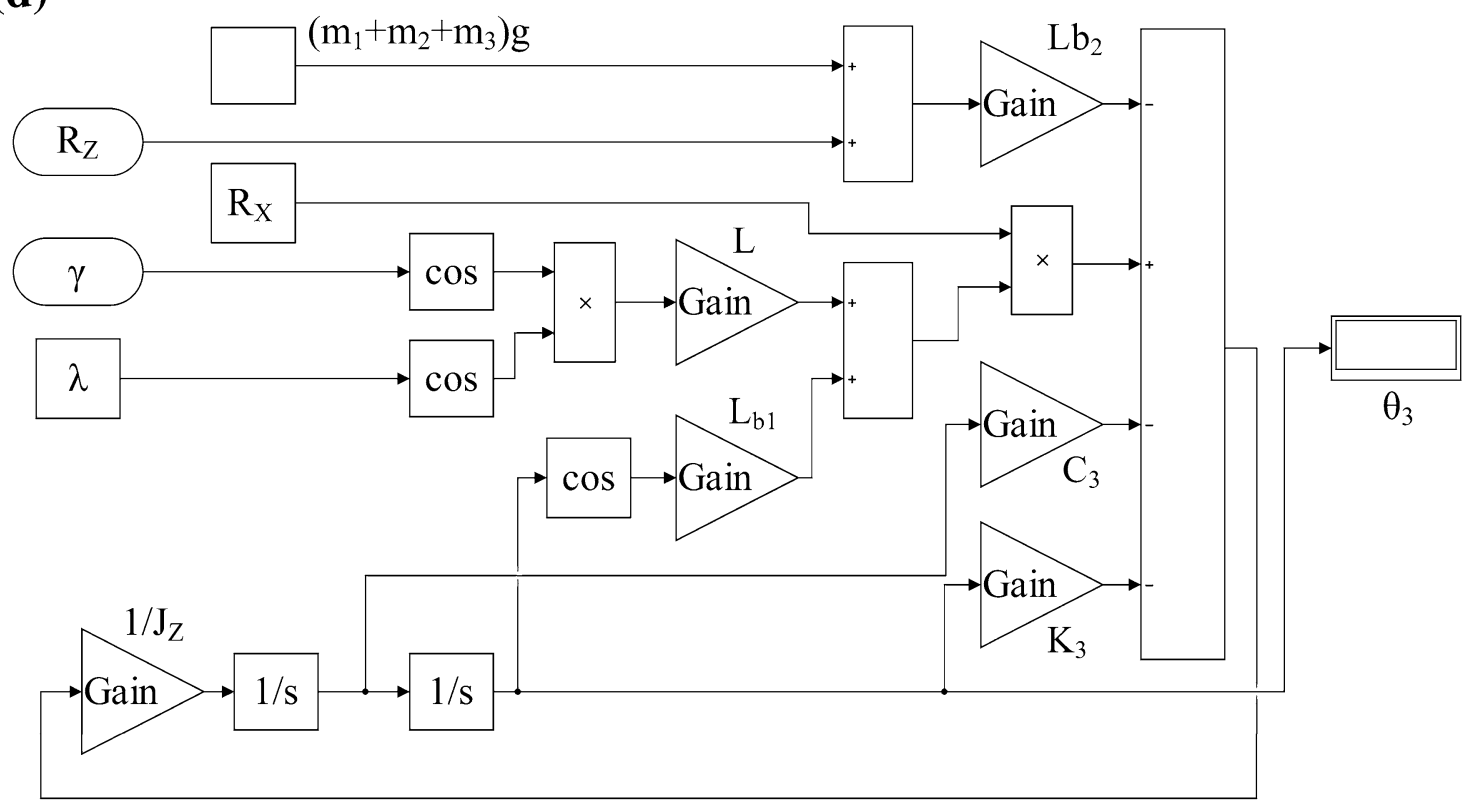

Fig. 8 (continued) 
Table 1 Initial parameters for simulation [17, 18]

\begin{tabular}{lll}
\hline Parameters & Value & Unit \\
\hline$m_{1}$ & 1600 & $\mathrm{Kg}$ \\
$m_{2}$ & 5700 & $\mathrm{Kg}$ \\
$m_{3}$ & 37,700 & $\mathrm{Kg}$ \\
$K_{1}$ & $6.31 \times 10^{7}$ & $\mathrm{~N} \mathrm{~m}^{-1}$ \\
$K_{2}$ & $7.45 \times 10^{6}$ & $\mathrm{~N} \mathrm{~m}^{-1}$ \\
$K_{3}$ & $1 \times 10^{4}$ & $\mathrm{~N} \mathrm{~m}^{-1}$ \\
$C_{1}$ & 400 & $\mathrm{~N} \mathrm{~s} \mathrm{~m}^{-1}$ \\
$C_{2}$ & $3.49 \times 10^{4}$ & $\mathrm{~N} \mathrm{~s} \mathrm{~m}^{-1}$ \\
$C_{3}$ & 10 & $\mathrm{~N} \mathrm{~s} \mathrm{~m}^{-1}$ \\
$J_{X}$ & 118,123 & $\mathrm{Kg} \mathrm{m}^{2}$ \\
$J_{Y}$ & 25,381 & $\mathrm{Kg} \mathrm{m}^{2}$ \\
$J_{Z}$ & $1.05 \times 10^{5}$ & $\mathrm{Kg} \mathrm{m}^{2}$ \\
$a$ & 1.15 & $\mathrm{~m}$ \\
$b$ & 2.95 & $\mathrm{~m}$ \\
$L$ & 3.9 & $\mathrm{~m}$ \\
$L_{y}$ & 1.75 & $\mathrm{~m}$ \\
\hline
\end{tabular}

\subsubsection{Response regularities of the attitude angles during horizontal cutting process}

During the horizontal cutting process, the horizontal swing angle of the cutting arm is a variable, while the vertical swing angle of the cutting arm is a constant. As to EBZ-160 type roadheader, the horizontal swing range of the cutting arm on left or right side is $0-24^{\circ}$. Therefore, the solving results of the dynamical model are analyzed with the cutting load and horizontal swing angle of the cutting arm, as shown in Figs.10, 11 and 12 .

The pitch angle varies most greatly, which can reach up to $9.1^{\circ}$, the variation amplitude of roll angle is the smallest, whose maximum is $2.4^{\circ}$, and the deviation angle can reach up to $7^{\circ}$. The variations of three attitude parameters of roadheader are greatly influenced by the cutting load, and they will increase accordingly as the cutting load increases, while the influence of horizontal swing angle of the cutting arm is slight.

\subsubsection{Response regularities of the attitude angles during vertical cutting process}

During the vertical cutting process, the vertical swing angle of the cutting arm is a variable, and its varying range is $-24^{\circ}$ to $38^{\circ}$ on EBZ-160 type roadheader, while the horizontal swing angle is a constant. Therefore, the solving results of the dynamical model are analyzed with the cutting load and vertical swing angle of the cutting arm, as shown in Figs.13, 14 and 15.
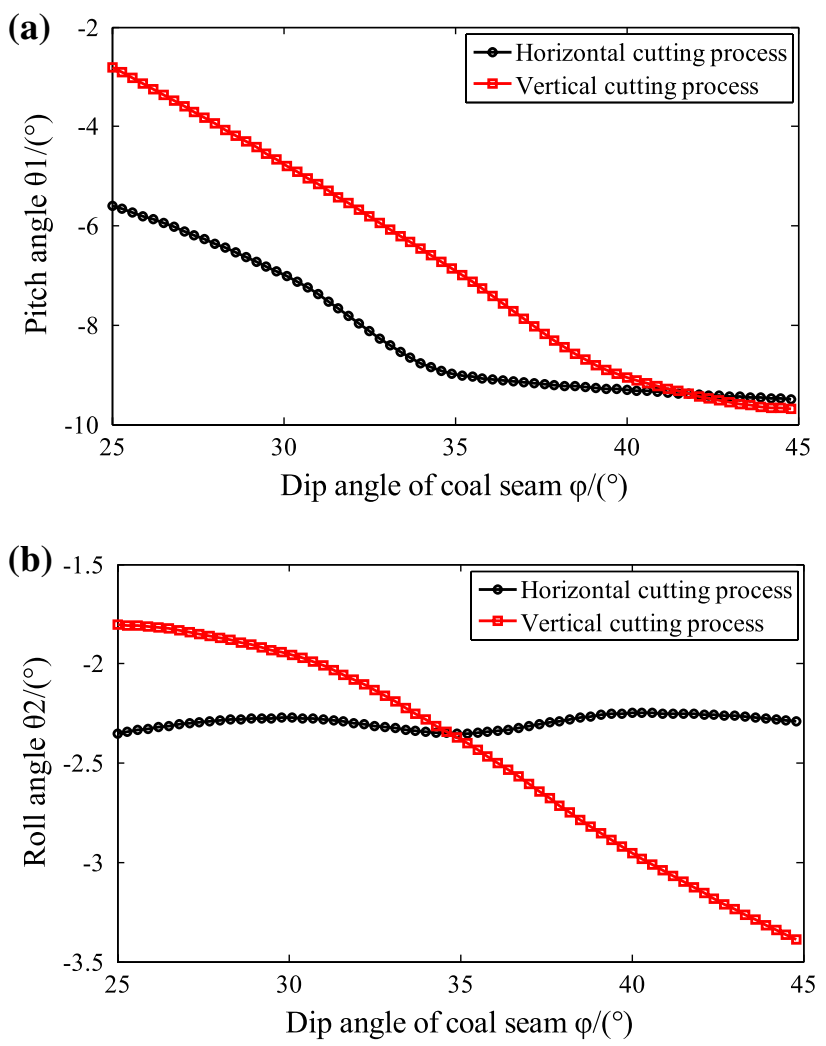

Fig. 9 Relationship between the attitude angles and dip angle of coal seam. (a) Pitch angle and dip angle of coal seam; (b) Roll angle and dip angle of coal seam

Similarly, the pitch angle varies most greatly, which can reach up to $8.7^{\circ}$, the variation amplitude of roll angle is the smallest, whose maximum is $3^{\circ}$, and the deviation angle can reach up to $6.4^{\circ}$. When the cutting load increases, the pitch decreases slightly at first and then increases, the roll angle increases all along, and the deviation angle increases at first and then reaches to a stable value. Unlike the horizontal cutting process, the change of vertical swing angle of the cutting arm has greater influence on the three attitude parameters. When the vertical swing angle of the cutting arm increases, all of the three attitude parameters decrease at first and then increase, whose minimum points are at $\gamma=0$.

According to the above analysis, the dip angle of coal seam will not affect the change of deviation angle. Therefore, the response regularities of the deviation angle during vertical cutting process in steep coal seam, depicted in Fig. 15a, are same to the results in flat coal seam, presented in our previous work [18], which indicates that the response results of the deviation angle are constant in different coal seams. 


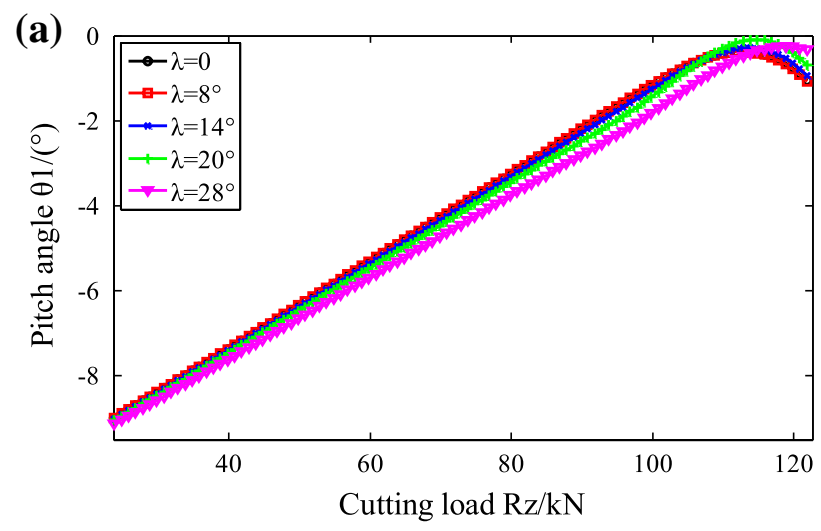

(b)

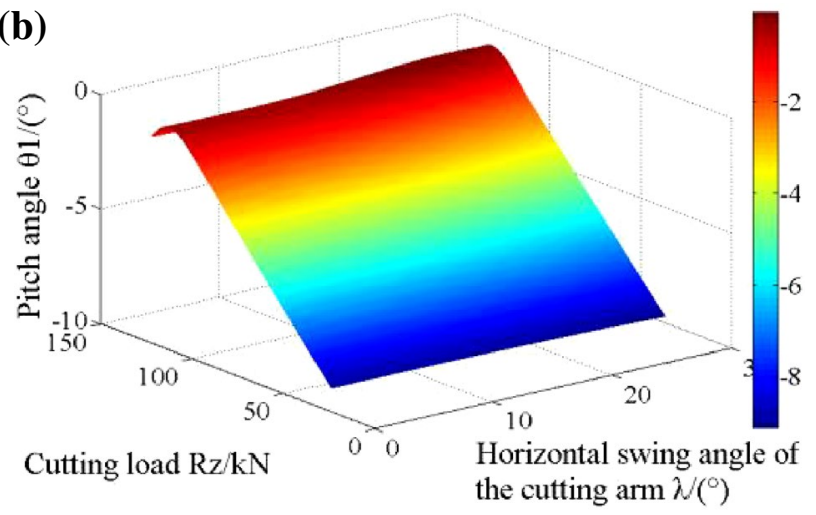

Fig. 10 Response regularities of the pitch angle during the horizontal cutting process. (a) Relationship between the pitch angle and the cutting load. (b) Relationship of the pitch angle, cutting load and horizontal swing angle of the cutting arm

\section{Experimental validation}

EBZ160-type roadheader is selected to conduct field experiments. There is no roof pressure, less coal dust and water content in the selected coal seam for experiments. The thickness of the coal seam is about $4 \mathrm{~m}$. The hardness coefficient is $3.0<f<4.0$, with less gangue. The size of roadway cross-section is $4 \times 4.5 \mathrm{~m}$, where the height is $4 \mathrm{~m}$ and the width is $4.5 \mathrm{~m}$.

The pressure of the driving cylinders is detected by BYD-60 type mining explosion-proof pressure transmitter. Vertical swing angle of the cutting arm, the pitch angle and roll angle of roadheader are measured by intrinsic

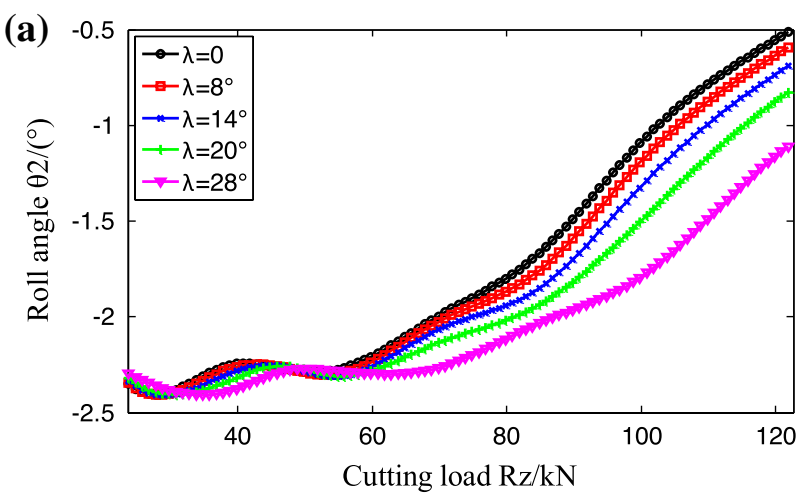

(b)

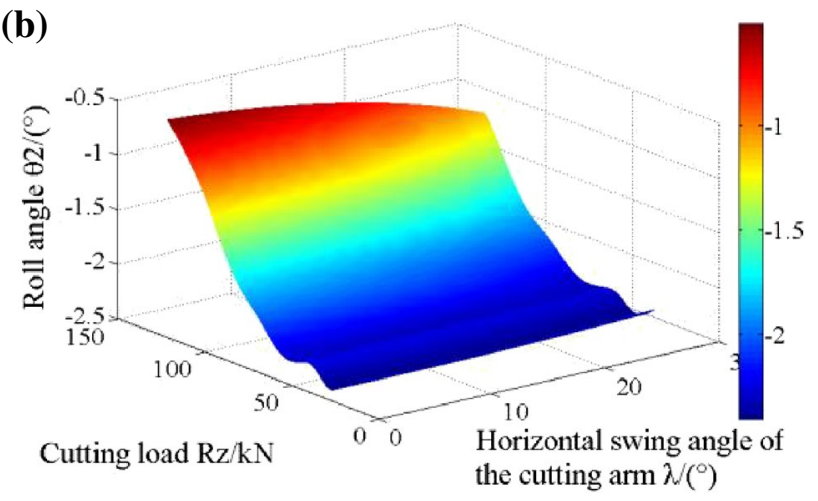

Fig. 11 Response regularities of the roll angle during the horizontal cutting process. (a) Relationship between the roll angle and the cutting load; (b) Relationship of the roll angle, cutting load and horizontal swing angle of the cutting arm

safety type GUC360 mining angle sensors. Horizontal swing angle of the cutting arm is measured by W18LD type dual speed sensor. The pictures of the selected sensors are shown in Fig. 16.

The deviation angle is measured by a fan-shaped laser and two laser targets. As measuring the deviation angle, the fan-shaped laser is emitted from the rear direction of roadheader, and two laser targets are installed on the body of roadheader to receive the fan-shaped laser. The experimental principle is shown in Fig. 17.

The centers of two laser targets are expressed by point $\mathrm{O}_{1}$ and $\mathrm{O}_{2}$, which are both on the center line of the body of roadheader. The intersection points of the fan-shaped 


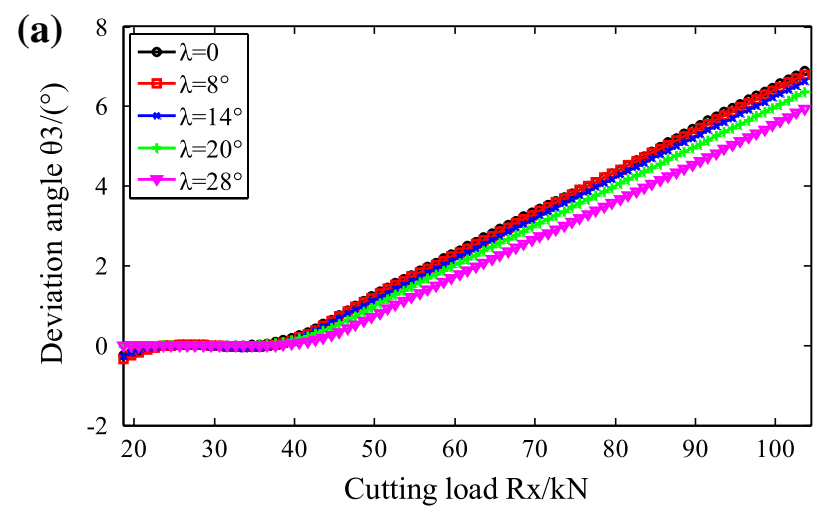

(b)

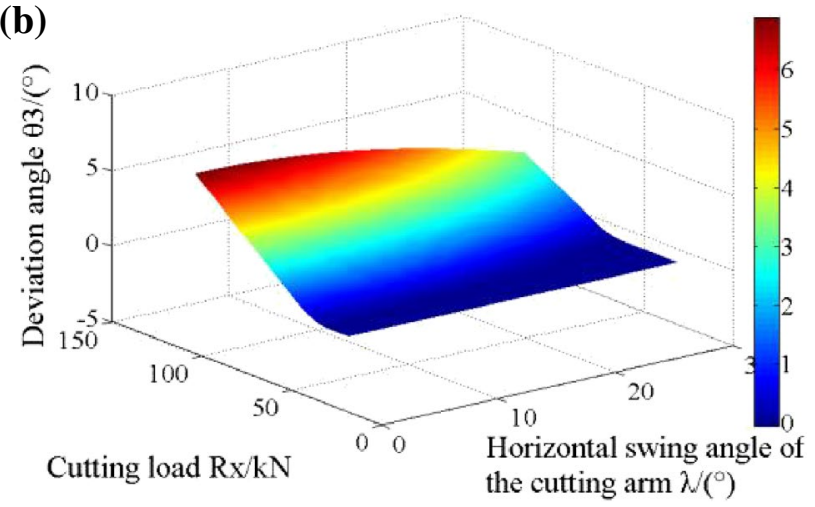

Fig. 12 Response regularities of the deviation angle during the horizontal cutting process. (a) Relationship between the deviation angle and cutting load; (b) Relationship of the deviation angle, cutting load and horizontal swing angle of the cutting arm

laser and two laser targets are expressed by point $S_{1}$ and $\mathrm{S}_{2}$. Then the calculation method of the deviation angle is:

$\theta_{3}=\arctan \frac{\left|O_{1} S_{1}\right|-\left|O_{2} S_{2}\right|}{\left|O_{1} O_{2}\right|}$

According to the calculation method of the cutting load in Sect. 3, the cutting load of any cutting condition can be calculated by pressure of the driving cylinders and swing angle of the cutting arm. The experimental data of attitude angle is processed with the cutting load, and the results are shown in Figs.18, 19 and 20.
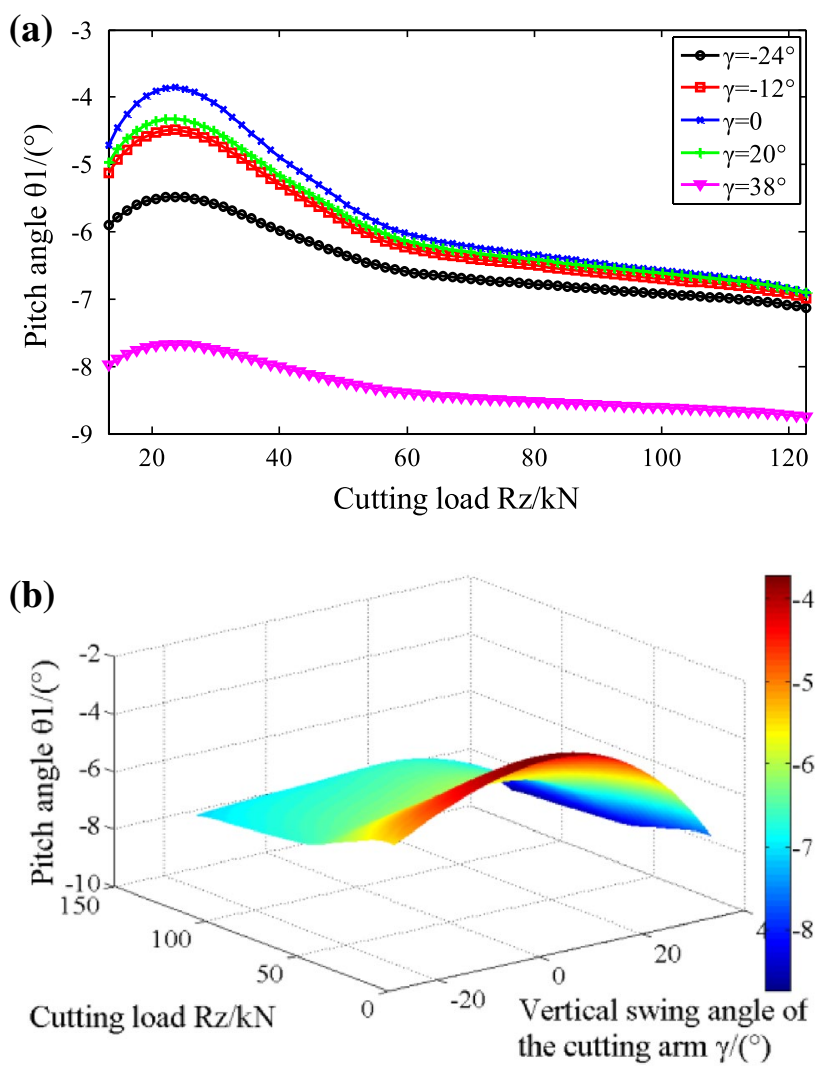

Fig. 13 Response regularities of the pitch angle during the vertical cutting process. (a) Relationship between the pitch angle and the cutting load; (b) Relationship of the pitch angle, cutting load and vertical swing angle of the cutting arm

According to Figs.18, 19 and 20, the experimental results are basically consistent with the simulation results. The response regularities of the attitude angle during cutting process are verified, and the theoretical model is validated.

\section{Conclusions}

A calculating method of the cutting load was proposed, in which the detailed formulations were derived. The pressure of the driving cylinders and swing angle of the cutting 


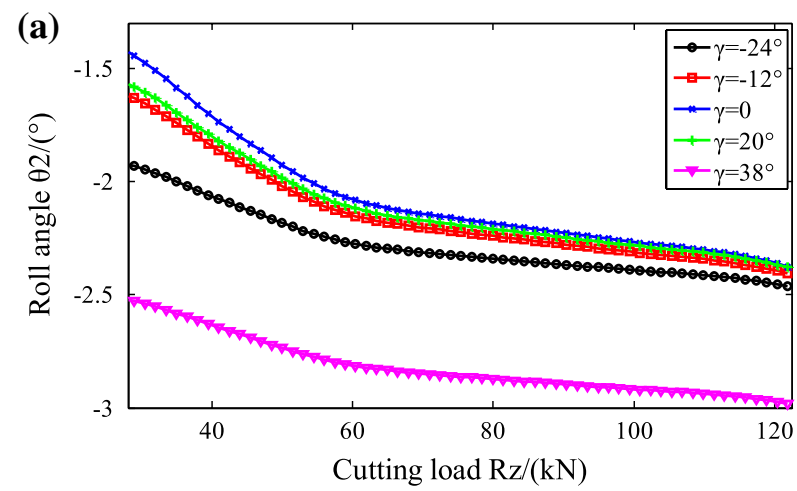

(b)

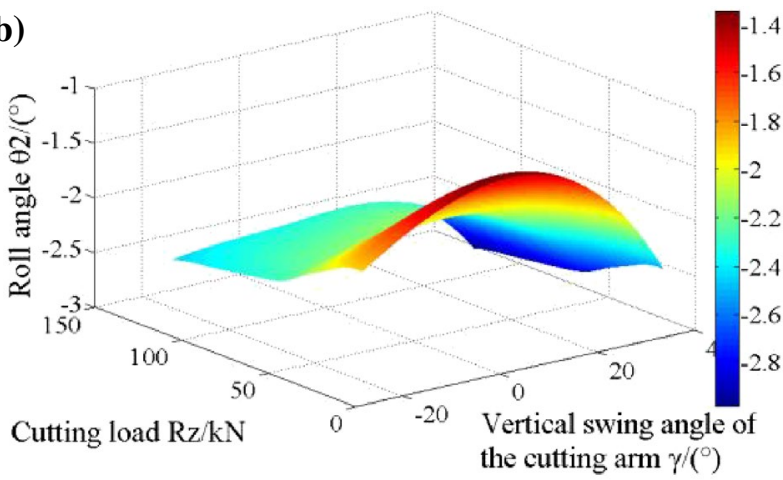

Fig. 14 Response regularities of the roll angle during the vertical cutting process. (a) Relationship between the roll angle and the cutting load; (b) Relationship of the roll angle, cutting load and vertical swing angle of the cutting arm

arm can be measured at real time, thus the cutting load can be calculated at real time during the cutting process. As is well known, the cutting load is valuable for estimation and control of the operating state of roadheader, hence the calculating method of the cutting load proposed in this paper, has definite guiding significance for many cases in practice.

The dynamical model of roadheader's attitude angles were established, which has practical reference value for many dynamic problems of roadheader. Focused on the condition of steep coal seam, the response characteristics of the attitude angles under influence of different factors, were revealed through parametric analysis of solving results of the dynamical model. Specifically, the pitch angle and deviation angle vary relatively greatly, which should be mainly considered in attitude rectification and (a)

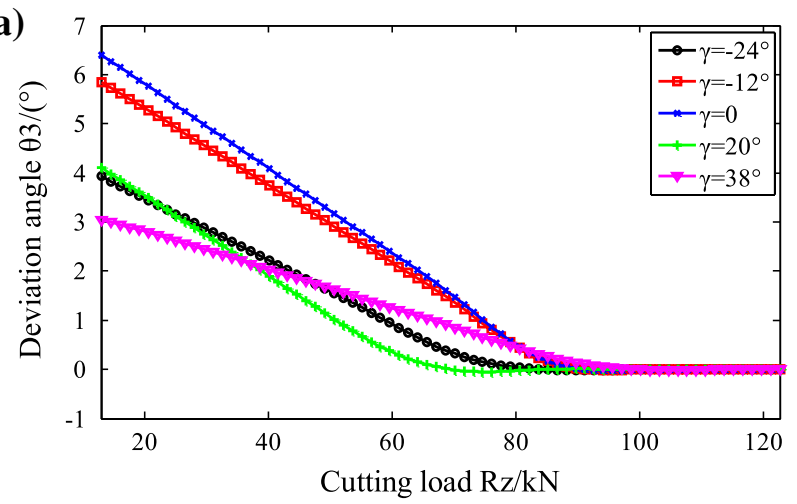

(b)

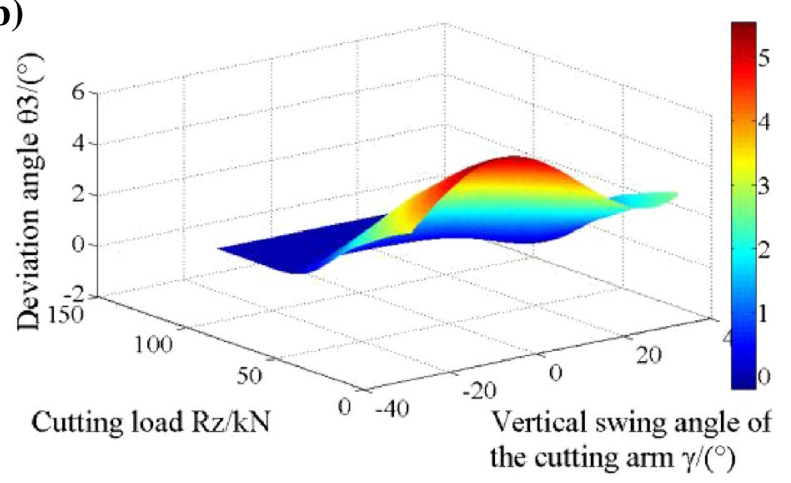

Fig. 15 Response regularities of the deviation angle during the vertical cutting process. (a) Relationship between the deviation angle and cutting load [18]; (b) Relationship of the deviation angle, cutting load and vertical swing angle of the cutting arm (a)

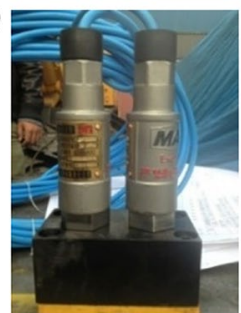

(b)

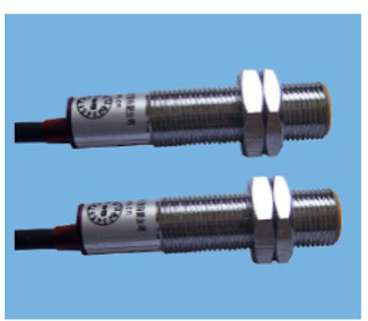

(c)

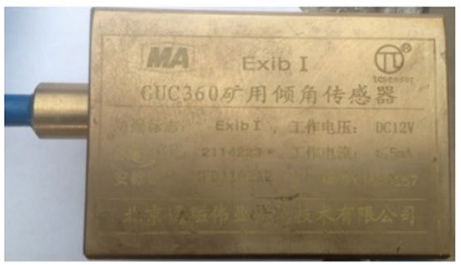

Fig. 16 Pictures of the experimental equipment $[17,18]$. (a) Pressure transmitter; (b) Dual speed sensor; (c) Angle sensor 
(a)

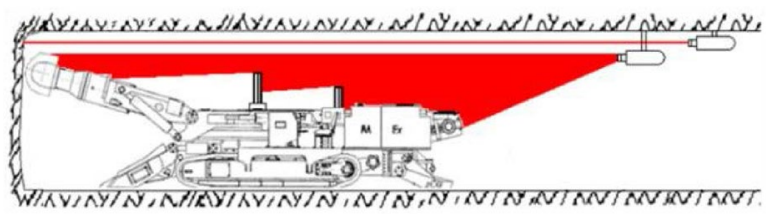

(b)

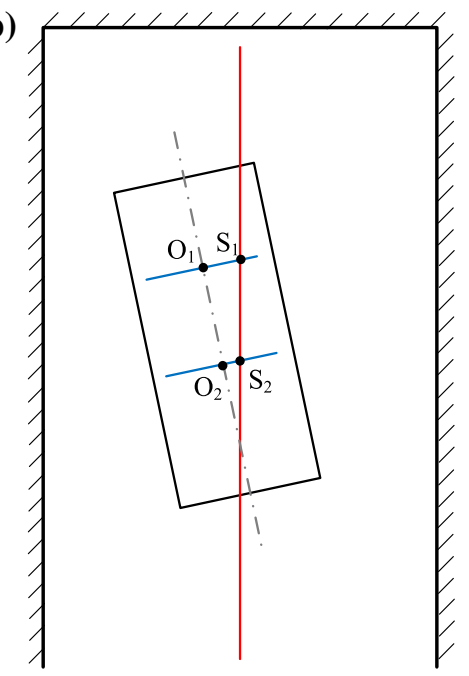

Fig. 17 Schematic diagram of measurement principle of the deviation angle. (a) Emitting and receiving of the fan-shaped laser; (b) Calculation of the deviation angle

control of the overall unit of roadheader in steep coal seam.

The research results of this paper can provide useful basis for prediction of roadheader's operating status, rectification of the attitude, and improvement of the overall stability in steep coal seam. Among the influence factors, the cutting load can be calculated by the proposed method, the swing angle of the cutting arm and dip angle of steep coal seam can be measured at real time. Therefore, the variations of roadheader's attitude can be predicted accurately, on basis of the analysis results in this paper.

The theoretical model presented in this paper, has coupled many important parameters, including attitude angles of roadheader, cutting conditions, and influence factors, upon which the dynamic analysis of
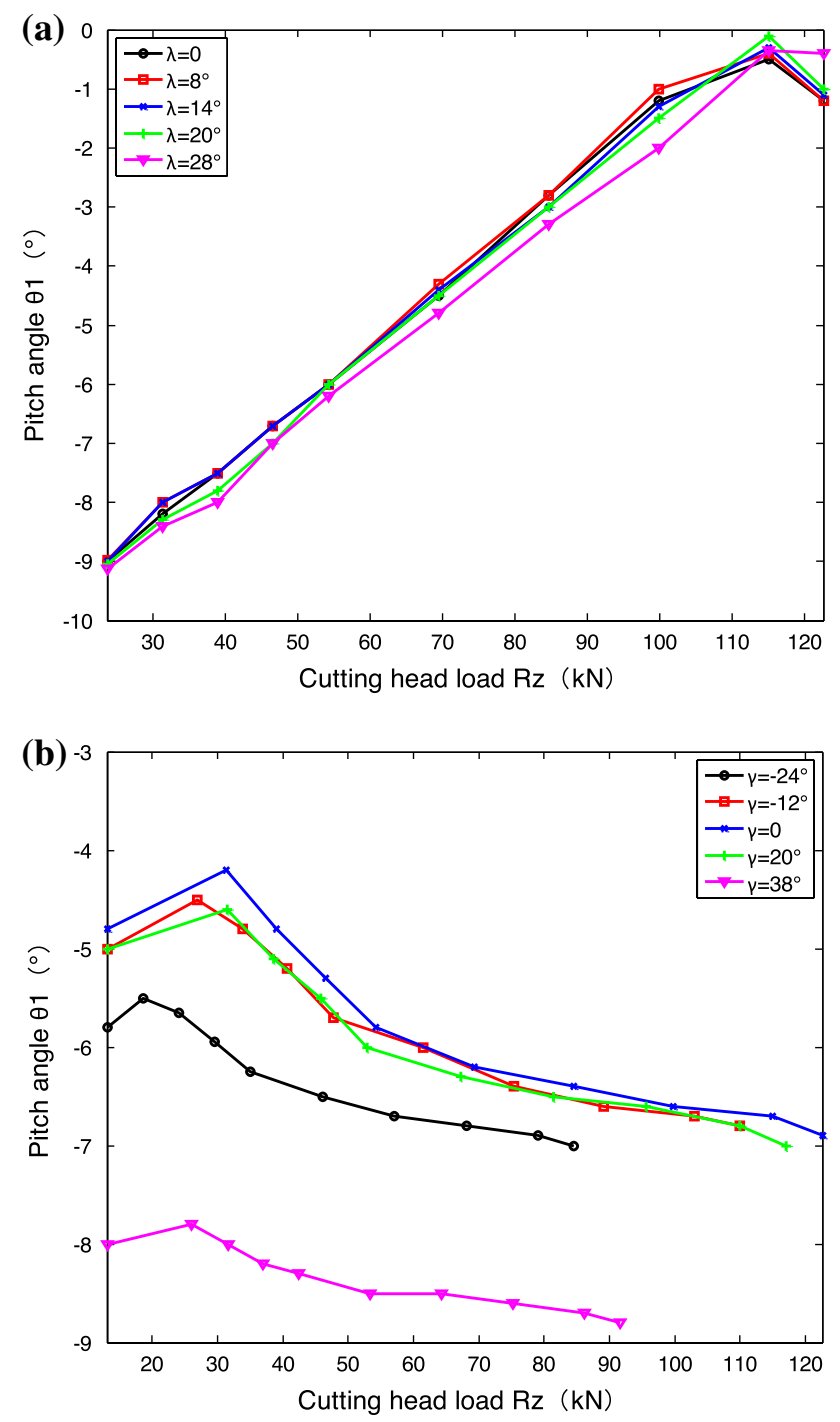

Fig. 18 Experimental results of the pitch angle. (a) During horizontal cutting process; (b) During vertical cutting process

roadheader can be carried out comprehensively and thoroughly. From another perspective, the formulation of the established model is relatively complex, so the analytic solutions are unavailable, which might lead to slight errors of the numerical results of this study. 

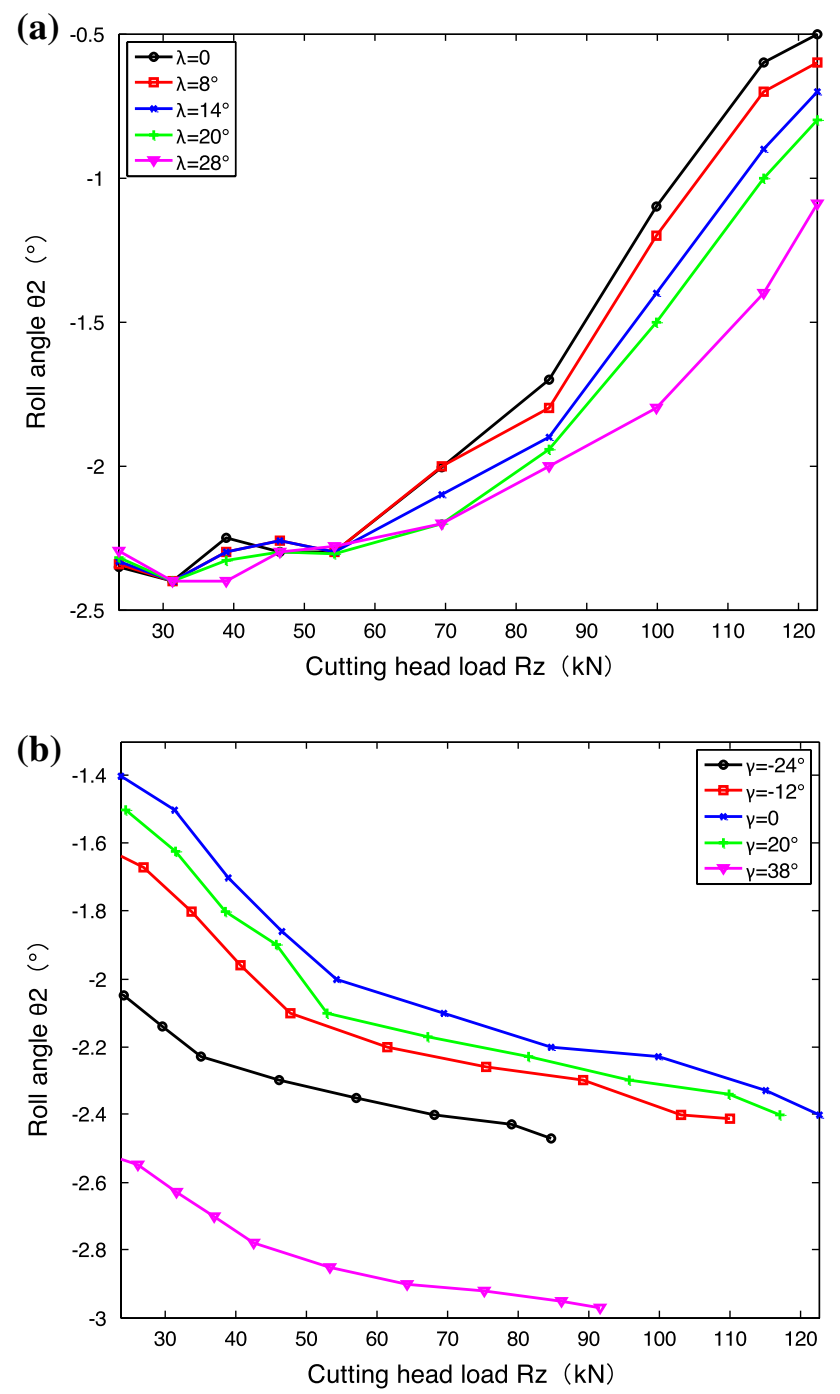

Fig. 19 Experimental results of the roll angle. (a) During horizontal cutting process; (b) During vertical cutting process

Therefore, improvement of the modeling method with available analytic solutions, should be concerned in further studies.

Acknowledgements This work is supported by the National Natural Science Foundation of China (51874308). Besides, the experimental data and appropriate information are provided by the previous researchers in our team, and are permitted for publication.

Funding National Natural Science Foundation of China (51874308).

Code availability The simulating system of Simulink was established in Matlab 2014a and the experiment data was processed by Matlab 2014a as well.

Data availability The data of this research will be shared under private communication with the corresponding author.
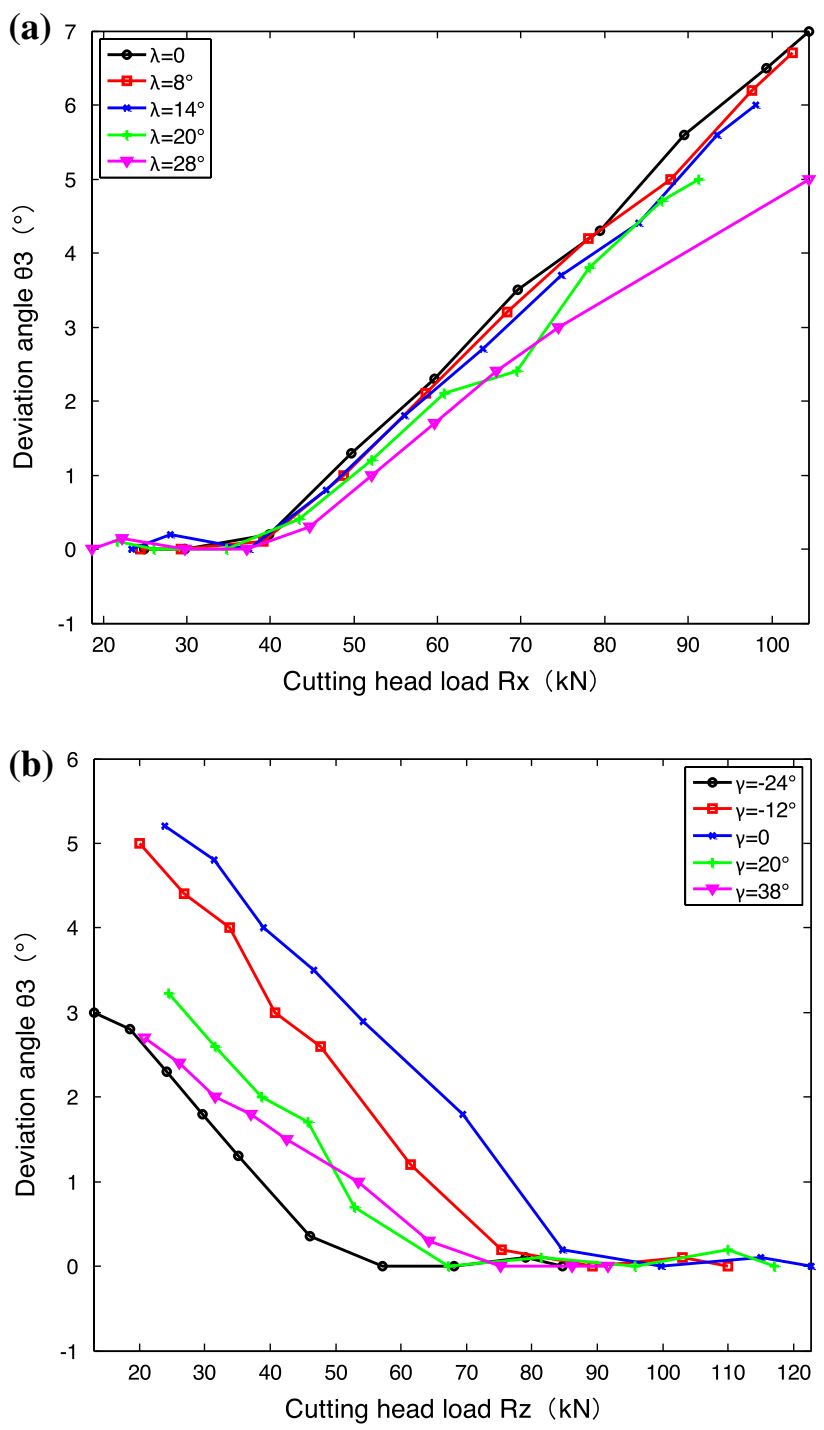

Fig. 20 Experimental result of the deviation angle. (a) During horizontal cutting process; (b) During vertical cutting process

\section{Declarations}

Conflict of interest The authors declare that there is no conflict of interest regarding the publication of this paper.

Open Access This article is licensed under a Creative Commons Attribution 4.0 International License, which permits use, sharing, adaptation, distribution and reproduction in any medium or format, as long as you give appropriate credit to the original author(s) and the source, provide a link to the Creative Commons licence, and indicate if changes were made. The images or other third party material in this article are included in the article's Creative Commons licence, unless indicated otherwise in a credit line to the material. If material is not included in the article's Creative Commons licence and your intended use is not permitted by statutory regulation or exceeds the permitted use, you will need to obtain permission directly from the copyright holder. To view a copy of this licence, visit http://creativecommons. org/licenses/by/4.0/. 


\section{References}

1. Jiang MR, Xiao XJ (2020) Analysis of coal supply and demand situation in 2019 and outlook for 2020. Energy China 042:9-13

2. Wu FF, Liu CY, Li JW (2014) Combination hydraulic support stability of working face in large inclined and "threesoft" thick seam. J Min Saf Eng 31(5):721-725

3. Hargrave CO, James CA, Ralston JC (2017) Infrastructure-based localisation of automated coal mining equipment. Int J Coal Sci Technol 4(3):252-261

4. Wang JH (2014) Development and prospect on fully mechanized mining in Chinese coal mines. Int J Coal Sci Technol 1(3): $153-260$

5. Wang $\mathrm{H}$ (2010) The 40 years developmental review of the fully mechanized mine roadway heading technology in China. J China Coal Soc 35:1815-1820

6. Liu S, Ji H, Liu X (2017) Effect of pick working angle on the cutting performance of a cutting head. J Braz Soc Mech Sci Eng 39(10):4147-4159

7. Li X, Huang B, Ma G et al (2013) Study on roadheader cutting load at different properties of coal and rock. Sci World J. https://doi.org/10.1155/2013/624512

8. Sun HF, Yang YM, Ju Y et al (2014) Numerical analysis of deformation, failure and energy release mechanisms of fractured coal rock under unloading conditions. J China Coal Soc 39(02):258-272

9. Liu Z, Du C, Jiang H et al (2017) Analysis of roadheader for breaking rock containing holes under confining pressures. Energies 10(8):1154

10. Li XH (2005) Study of dynamic behaviour of horizontalaxial-roadheader as transverse cutting. Chin J Constr Mach 01:73-75

11. Li XH, He Y, Li T, Yang TT (2014) Analysis of horizontal and vertical random vibration responses of longitudinal roadheader. J China Coal Soc 03:580-585

12. Zhao L, Tian Z, Sun Y et al (2013) Vibration characteristics of a longitudinal roadheader. J Vib Shock 32(11):17-20

13. Yao JQ, Li XH, Zhao SQ, Jiao L (2011) Dynamic analysis and study of track vibration at longitudinal roadheaders cutting. Min Process Equip 39(11):4-8
14. He Y, Li XH (2018) Random vibration response analysis of longitudinal roadheader. Ind Mine Autom 44(03):87-91

15. Li X, Gu YZ, Wu M (2016) Kinematics analysis of roadheader's working mechanism based on differential geometry. J China Coal Soc 41(12):3158-3166

16. Wang J, Zhang Y, Dong L (2016) Analysis of vibration characteristics and dynamic load identification in continuous miner cutting arm. Int J Simul Syst Sci Technol 17(13):20.1-20.7

17. Zong K, Zhang P, Wang PJ et al (2018) Multifactor analysis of Roadheader's body pose responses during the horizontal cutting process. Shock Vib. https://doi.org/10.1155/2018/23874 08

18. Zong K, Fu SC, Li X, Wu M (2021) Modelling and response analysis of multibody large-scale displacement of boomtype roadheader. Proc Inst Mech Eng Pt K-J. https://doi.org/ 10.1177/14644193211012123

19. Yang YY, Jin DW (2009) Machinery system dynamics. Tsinghua University Press, Beijing

20. Song YH (2014) Dynamic simulation and finite element analysis of key structural parts for EBZ 160B Roadheader. Dissertation, Hebei University of Science and Technology

21. Jiang H, Du C, Liu S et al (2015) Numerical investigation on rock fragmentation by cutting head of roadheader based on fracture mechanics. J Vibroeng 17(5):2199-2211

22. Institute of theoretical mechanics of Harbin Institute of Technology (2009) Theoretical mechanics. I. Higher Education Press, Harbin

23. Chen YY (2012) The dynamic analysis and simulation of tracked vehicles. Dissertation, Shenyang Ligong University

24. Wang PX (2009) Study on stability for transverse-cutting of cantilevered roadheader. Coal Mine Mach 05:64-66

25. Li ZX, Wei JC, Liu Y (2005) Coal geology. Geological Publishing House, Beijing

Publisher's Note Springer Nature remains neutral with regard to jurisdictional claims in published maps and institutional affiliations. 